\title{
Grazing and utilization of chroococcoid cyanobacteria and heterotrophic bacteria by protozoa in laboratory cultures and a coastal plankton community
}

\author{
David A. Caron, Ee Lin Lim, Geraldine Miceli* ${ }^{*}$ John B. Waterbury, \\ Frederica W. Valois
}

Biology Department, Woods Hole Oceanographic Institution, Woods Hole, Massachusetts 02543, USA

\begin{abstract}
Field and laboratory experiments were conducted to compare the rates of ingestion of planktonic protozoa for chroococcoid cyanobacteria and heterotrophic bacteria, and the fate of this ingested biomass. Laboratory experiments tested the ability of cyanobacteria and bacteria to support the growth of 3 species of bacterivorous protozoa. Two species of heterotrophic bacteria supported faster growth rates and higher cell yields of the protozoa than 3 strains of cyanobacteria. When mixtures of bacteria and cyanobacteria were offered, however, all protozoa grew as rapidly as when bacteria were offered alone. One protozoan showed a marked feeding selectivity against 1 strain of cyanobacteria when offered mixtures of bacteria and cyanobacteria. Grazing rate measurements performed in Vineyard Sound, Massachusetts, USA, revealed removal rates as high as $54 \%$ of the cyanobacterial assemblage $\mathrm{d}^{-1}$ and $75 \%$ of the heterotrophic bacterial assemblage $\mathrm{d}^{-1}$ Nanoplanktonic protists (organisms $<20 \mu \mathrm{m}$ ) were the major consumers of both cyanobacterial and bacterial biomass in this environment on 5 sampling dates. Based on measurements of the ingestion rates of nanoplanktonic consumers and the carbon content of cyanobacteria and heterotrophic bacteria, we conclude that cyanobacterial biomass in this coastal environment at times reaches $30 \%$ of the total prokaryote biomass consumed by the nanoplankton. During times of peak abundance of chroococcoid cyanobacteria, this biomass is an important source of organic carbon for planktonic protozoa feeding on bacteriasized particles.
\end{abstract}

\section{INTRODUCTION}

Chroococcoid cyanobacteria of the genus Synechococcus are unicellular, photosynthetic picoplankton that have a wide geographical distribution. These microorganisms often occur at high cell densities in the euphotic zones of tropical and temperate oceans and some freshwater environments (Chang 1980, Waterbury et al. 1980, Cronberg \& Weibull 1981, Krempin \& Sullivan 1981, Landry et al. 1984, Caron et al. 1985b, Glover 1985, Murphy \& Haugen 1985, Fahnenstiel et al. 1986, Stockner \& Antia 1986, Waterbury et al. 1986, Pick \& Caron 1987, Glover et al. 1988, Olson et al. 1990). Synechococcus occurs in most tropical and sub-

\footnotetext{
- Present address: PO Box 1815, Kingston, Rhode Island 02881, USA
}

tropical oceans throughout the year at densities of $10^{3}$ to $10^{4}$ cells $\mathrm{ml}^{-1}$. In temperate waters, higher densities often occur and population abundances in these waters are strongly correlated with the annual cycle of water temperature (Caron et al. 1985b, Waterbury et al. 1986). In these latter environments, a bloom is initiated during the spring as the water temperature reaches ca $6{ }^{\circ} \mathrm{C}$. Cell densities increase rapidly to ca $10^{5}$ cells ml $\mathrm{ml}^{-1}$ and remain relatively high throughout the summer months (Waterbury et al. 1986).

High standing stocks of chroococcoid cyanobacteria in many aquatic environments have been shown to constitute a significant fraction of the total primary productivity of plankton ecosystems (Morris \& Glover 1981, Joint \& Pomroy 1983, Li et al. 1983, Platt et al. 1983, Takahashi \& Bienfang 1983, Caron et al. 1985b, Glover et al. 1986, Waterbury et al. 1986). The exact 
contribution of Synechococcus production to total production has been difficult to determine because of the problems associated with clean separation of this population from other primary producers but, on average, these studies have indicated that Synechococcus is probably responsible for 5 to $20 \%$ of the total primary productivity of most ecosystems in which it occurs. The contribution of Synechococcus to total primary productivity at particular depths, locations and times of year, however, may be significantly higher (up to 50-60\%; reviewed in Waterbury et al. 1986).

Despite the obvious importance of Synechococcus biomass in aquatic environments, there have been relatively few studies that have investigated the consumption of these microorganisms. These studies have employed a variety of techniques to measure grazing of cyanobacteria. Rates of removal of chroococcoid cyanobacteria from plankton communities have been estimated using diffusion chambers and the dilution technique (Landry et al. 1984), radioisotope-labeled prey (Iturriaga \& Mitchell 1986), metabolic inhibitors (Campbell \& Carpenter 1986) and direct cell counts (Waterbury et al. 1986). Grazing coefficients from these studies have varied considerably, from below the limit of detection up to ca $1.7 \mathrm{~d}^{-1}$. Most of these investigations have assumed that protozoa in the nanoplankton size class $(2.0$ to $20 \mu \mathrm{m})$ are the major consumers of chroococcoid cyanobacteria in the plankton because of the small size of the cyanobacteria (generally $\leq 1.0$ $\mu \mathrm{m})$, the role that small protozoa have been shown to play as grazers of heterotrophic bacteria, and some direct observations of the consumption of cyanobacteria by protozoa (Johnson et al. 1982, Iturriaga \& Mitchell 1986). Studies have yet to be performed, however, to quantify the grazing impact of various size classes of plankton on cyanobacterial assemblages.

There also are few data comparing the removal rates of cyanobacterial and bacterial assemblages from the same plankton community. The importance of bacterial productivity in pelagic ecosystems is now well established (Fuhrman \& Azam 1982, Cole et al, 1988), and numerous studies in recent years have examined the consumption of this biomass by microbial assemblages (recently reviewed in McManus \& Fuhrman 1988 and Pace 1988). The relative importance of these 2 microbial. groups to the nutrition of consumers capable of capturing picoplanktonic particles, however, is poorly known.

Field and laboratory experiments were conducted to examine the relative contributions of Synechococcus and heterotrophic bacteria to the diets of cultured species of protozoa (laboratory experiments) and the natural plankton assemblage of a neritic marine environment (field experiments). Three cultured protozoa exhibited species-specific differences in their ability to utilize cyanobacterial biomass. In general, protozoa offered only cyanobacteria as food grew, but more slowly than protozoa offered bacteria. Protozoa offered mixtures of cyanobacteria and bacteria, how. ever, grew rapidly. In only one case did protozoa actively select against the cyanobacteria when both bacteria and cyanobacteria were present at high abundance. During field experiments performed in Vineyard Sound, Massachusetts, nanoplanktonic organisms $(<20 \mu \mathrm{m})$ were the major consumers of cyanobacteria. Ingestion rates of these protozoa (cells consumed nanoplankter ${ }^{-1} \mathrm{~d}^{-1}$ ) were 2 orders of magnitude greater for bacteria than for cyanobacteria. Clearance rates ( $\mathrm{nl}$ cleared nanoplankter ${ }^{-1} \mathrm{~h}^{-1}$ ), however, were comparable for both prey types.

\section{MATERIALS AND METHODS}

Laboratory experiments. Laboratory experiments were conducted with 3 clonal cultures of marine protozoa (a bacterivorous nanoflagellate, Paraphysomonas sp., an unidentified hymenostome ciliate and an unidentified scuticociliate). These organisms were isolated from seawater samples from Massachusetts coastal waters that were enriched with sterile rice grains to promote bacterial growth. Stock cultures of the protozoa were maintained on a mixed bacterial assemblage grown in 0.01 to $0.05 \%$ yeast extract. Each protozoan species was offered 2 species of bacteria (Pseudomonas halodurans and Serratia marinorubra) and 3 strains of Synechococcus (strain designations WH7803, WH8012, WH8101) separately and in various combinations for a total of 8 treatments (each species separately, and P. halodurans + each cyanobacterial strain).

Prey species were grown separately in 2.81 Fernbach flasks. The cyanobacteria were grown in ' $\mathrm{SN}$ ' medium (Waterbury et al. 1986) in full-strength aged Sargasso Sea seawater (rather than $3 / 4$ strength seawater), on a rotary shaker at $60 \mathrm{rpm}$ in continuous light at ca $50 \mu \mathrm{E}$ $\mathrm{m}^{-2} \mathrm{~s}^{-1}$. Bacteria were grown in $0.2 \%$ yeast extract in aged Sargasso Sea seawater on a rotary shaker Bacteria and cyanobacteria were harvested in late stationary phase, and the experimental treatments were prepared as described above. Initial prey densities are given in Table 1. Prey carbon and nitrogen content was measured in samples filtered onto pre-combusted Whatman GF/F glass fiber filters and analyzed using a Perkin Elmer 240 elemental analyzer. A set of flasks was then inoculated with each of the 3 protozoa and placed back on the shaker in continuous dark at $18 \pm$ $1{ }^{\circ} \mathrm{C}$. Flagellates were inoculated at densities of ca 100 to 1000 cells $\mathrm{ml}^{-1}$ and ciliates were inoculated at densities of ca 10 to 500 cells $\mathrm{ml}^{-1}$. The protozoan 
Table 1. Chemical composition and initial prey densities ( \pm 1 SD) and biomass values for 2 species of bacteria and 3 strains of chroococcoid cyanobacteria used as food for 3 cultured protozoa

\begin{tabular}{|c|c|c|c|c|c|}
\hline Prey species & $\begin{array}{l}\text { Carbon content } \\
\left(\text { fg cell }{ }^{-1}\right)\end{array}$ & $\begin{array}{l}\text { Nitrogen content } \\
\quad\left(\mathrm{fg} \mathrm{cell}^{-1}\right)\end{array}$ & $\begin{array}{c}C: N \text { ratio } \\
\text { (by weight) }\end{array}$ & $\begin{array}{l}\text { Initial density } \\
\left(\text { no. } \mathrm{ml}^{-1}\right)\end{array}$ & $\begin{array}{l}\text { Initial conc. of } \\
\text { prey carbon in } \\
\text { cultures }\left(\mathrm{mg} \mathrm{l}^{-1}\right)\end{array}$ \\
\hline Pseudomonas halodurans & $71 \pm 3$ & $22 \pm 1$ & $3.2 \pm 0.1$ & $1.72 \times 10^{8} \pm 0.20$ & 12.2 \\
\hline Serratia marinorubra & $61 \pm 20$ & $18 \pm 6$ & $3.3 \pm 0.2$ & $1.21 \times 10^{8} \pm 0.10$ & 7.4 \\
\hline Synechococcus strain WH8101 & $345 \pm 11$ & $75 \pm 2$ & $4.6 \pm 0.0$ & $3.53 \times 10^{7} \pm 3.38$ & 12.1 \\
\hline Synechococcus strain WH8012 & $60 \pm 5$ & $14 \pm 1$ & $4.2 \pm 0.2$ & $1.45 \times 10^{8} \pm 0.15$ & 8.7 \\
\hline Synechococcus strain WH7803 & $347 \pm 40$ & $83 \pm 10$ & $4.2 \pm 0.1$ & $2.65 \times 10^{7} \pm 1.16$ & 9.2 \\
\hline $\begin{array}{l}\text { P. halodurans } \\
\text { and WH8101 }\end{array}$ & & & & $\begin{array}{l}8.57 \times 10^{7} \pm 1.31 \\
1.82 \times 10^{7} \pm 0.44\end{array}$ & 12.4 \\
\hline $\begin{array}{l}\text { P. halodurans } \\
\text { and WH8012 }\end{array}$ & & & & $\begin{array}{l}7.15 \times 10^{7} \pm 0.95 \\
8.15 \times 10^{7} \pm 1.08\end{array}$ & 10.0 \\
\hline $\begin{array}{l}\text { P. halodurans } \\
\text { and WH } 7803\end{array}$ & & & & $\begin{array}{l}6.89 \times 10^{7} \pm 1.07 \\
1.95 \times 10^{7} \pm 0.27\end{array}$ & 11.7 \\
\hline
\end{tabular}

inocula were removed from stock cultures in the late stationary growth phase. The background bacterial densities in these cultures were generally $\leq 10^{6}$ bacteria $\mathrm{ml}^{-1}$ and therefore contributed an insignificant number of bacteria to the experimental treatments $\left(\leq 10^{4}\right.$ bacteria $\mathrm{ml}^{-1}$ ).

Samples were taken periodically from each of the flasks for cell counts of the protozoa and their prey. Protozoa and bacteria were enumerated using the acridine orange epifluorescence microscopical technique (Davis \& Sieburth 1982). Cyanobacteria were counted by epifluorescence microscopy using the autofluorescence of the photosynthetic pigments to visualize the cells (Waterbury et al. 1979). Protozoan cell yields (protozoa produced per unit of prey biomass consumed) were determined for each treatment based on the disappearance of prey organisms during the time interval from the beginning of the grazing experiment to the end of the exponential growth period of each protozoan, the carbon content of the prey, and the number of protozoa produced during this time interval. In 2 treatments in which cyanobacteria were offered as prey the cyanobacteria did not support abundant and/ or rapid growth of the protozoa, and the stationary growth period was not reached before the end of the experiment. Cell yields of the protozoa were not obtained for these treatments.

Field experiments. Grazing experiments were conducted on 5 days during June and July 1987 at the Woods Hole Oceanographic Institution Shore Laboratory facility, Woods Hole, Massachusetts. Each experiment was performed with Vineyard Sound seawater collected before dawn ca $20 \mathrm{~m}$ from the shore. All experiments were started within $0.5 \mathrm{~h}$ of collection. Incubation vessels were $900 \mathrm{ml}$ polystyrene tissue culture flasks. All incubations were performed at in situ water temperature (range $=17.0$ to $20.6^{\circ} \mathrm{C}$ ) in natural sunlight. Sunlight was reduced to $50 \%$ ( 9 and 16 June) or to $30 \%$ (29 June and 28 July) of incident radiation with neutral-density Mylar acetate sheets to avoid photoinhibition of the Synechococcus. The possibility of light inhibition of the growth of Synechococcus was further tested in 2 separate experiments performed on 16 July and 19 August. Unfiltered seawater samples with and without eukaryotic metabolic inhibitors (see below) wrere incubated at $100,50,30$ and $10 \%$ of incident light.

Water samples were divided into 4 treatments performed in duplicate: seawater without any pretreatment, unfiltered seawater with eukaryotic inhibitors, seawater passed gently through $210 \mu \mathrm{m}$ Nitex screening, and seawater passed gently through $20 \mu \mathrm{m}$ Nitex screening. The eukaryotic inhibitors colchicine and cyclohexamide (Sigma Chemical Co.) were added at concentrations of 100 and $200 \mathrm{mg} \mathrm{l}^{-1}$, respectively. These inhibitors have been used effectively to stop grazing by unicellular eukaryotes without direct adverse effects on prokaryote growth (Sherr et al. 1986, Weisse 1989). However, cessation of grazing may lead to a reduction in regenerated nutrients for the growth of primary producers. In order to prevent nutrient ( $\mathrm{N}$ or P) limitation of the cyanobacteria, $\mathrm{NH}_{4} \mathrm{Cl}$ and $\mathrm{K}_{2} \mathrm{PO}_{4}$ were added at a final concentration of 1.0 and $0.1 \mu \mathrm{M}$, respectively, to an additional eukaryotic-inhibited treatment for each experiment. Metabolic inhibitors were added $1 \mathrm{~h}$ prior to the initial sampling time to provide time for the inhibitors to stop grazing activity (Sherr et al. 1986).

The effectiveness of the metabolic inhibitors for stopping grazing by natural assemblages of protozoa was examined by quantifying the rate of ingestion of fluorescent microspheres $(0.57 \mu \mathrm{m}$ Fluoresbrite carb- 
oxylate latex microspheres, Polysciences, Inc.) in unfiltered seawater samples with and without inhibitors, and in seawater passing a $20 \mu \mathrm{m}$ screen. Experimental conditions were identical to the grazing experiments described above. Microspheres were added at a final concentration of $6 \times 10^{5} \mathrm{ml}^{-1}$ to water samples collected from Vineyard Sound on 28 August, and subsamples were taken initially and at several times over a $24 \mathrm{~h}$ period. All samples were preserved with a mixture of $2 \%$ glutaraldehyde and $2 \%$ tannic acid added to the sample at a ratio of $1: 1$. This preservative is a modification of the Sieracki et al. (1987) method that we have tested and found to be effective in preventing egestion of food particles by protozoa during fixation (unpubl. obs.). Preserved samples were filtered onto Irgalan Black stained Nuclepore filters of $1.0 \mu \mathrm{m}$ pore size, rinsed with $95 \%$ ethanol to reduce tannic acid precipitates, and stained with acridine orange (Davis \& Sieburth 1982). The number of ingested microspheres in nanoplanktonic protozoa was determined for each treatment by epifluorescence microscopy.

The effect of the eukaryotic inhibitors on growth of Synechococcus was examined in culture using Synechococcus strain WH7803. The cyanobacterium was grown at $22^{\circ} \mathrm{C}$ in continuous light at ca 50 to $100 \mu \mathrm{E} \mathrm{m} \mathrm{m}^{-2} \mathrm{~s}^{-1}$ in $\mathrm{SN}$ medium with and without inhibitors added. The effect of the metabolic inhibitors also was examined in the field experiments by comparing the growth of Synechococcus in seawater gently filtered through a Nuclepore filter of $1.0 \mu \mathrm{m}$ pore size (i.e. most grazers removed) with growth in unfiltered seawater to which metabolic inhibitors were added. The $<1.0 \mu \mathrm{m}$ fraction was obtained by a serial gravity filtration of whole seawater through 210,20 and $10 \mu \mathrm{m}$ screening, and finally through a $1.0 \mu \mathrm{m}$ Nuclepore filter. Concentrations of Synechococcus in the filtrate were generally 15 to $20 \%$ of the density in the unfiltered seawater.

Rates of removal of Synechococcus and bacteria in the field experiments were calculated from the changes in the cell densities between inhibited and uninhibited samples over the course of $24 \mathrm{~h}$. Although we enumerated the densities of bacteria and cyanobacteria in the experimental vessels at $12 \mathrm{~h}$, changes in the abundances of these populations were not large for many of the samples by this time and grazing rates were calculated only for the $24 \mathrm{~h}$ sample. Samples from each treatment were preserved with $10 \%$ glutaraldehyde at a final concentration of $1 \%$. Synechococcus counts were performed immediately after sampling to prevent fading during storage. Populations were enumerated by epifluorescence microscopy as described above. Bacteria were counted by epifluorescence microscopy using the DAPI technique (Porter \& Feig 1980) with a final stain concentration of 3 to $5 \mu \mathrm{g} \mathrm{ml}^{-1}$. Although a large number of cells and multiple slides were counted for each sample, differences between treatments of less than ca $15 \%$ were not considered significant because of the combined variabilities of the counting error that is inherent in the microscopical technique and the variability between replicate flasks. For this reason, and to maintain consistency in our calculations, we calculated grazing rates only for the time interval between 0 and $24 \mathrm{~h}$ but not for shorter time periods. In some cases decreases in the prey densities were greater during the 0 to $12 \mathrm{~h}$ time interval (e.g. in the $<20 \mu \mathrm{m}$ treatments), but this effect did not always occur. Grazing rates calculated over the $24 \mathrm{~h}$ time interval probably represent conservative estimates of the actual grazing rate.

\section{RESULTS}

\section{Laboratory studies}

We compared the suitability of 3 strains of Synechococcus and 2 species of bacteria as food for 3 bacterivorous protozod. The carbon and nitrogen contents, $\mathrm{C}: \mathrm{N}$ ratios, and the initial densities and biomass values of the 5 prey types in the laboratory treatments are given in Table 1. All prey types had consistently low C:N ratios characteristic of bacterial and cyanobacterial biomass (Cuhel \& Waterbury 1984, Nagata 1986). The 2 bacterial species and cyanobacterial strain WH8012 were similar in carbon content 160 to $71 \mathrm{fg} \mathrm{C}$ cell $^{-1}$ ) while cyanobacterial strains WH8101 and WH7803 were 5 to $6 \times$ larger than the latter microorganisms. Initial cell densities and biomass values were quite high in the treatments, and presumably represented saturating prey concentrations for the protozoa in all cases.

The 3 cultured protozoa grew rapidly on the 2 heterotrophic bacteria in the laboratory (Table 2; Fig. 1). Synechococcus also supported the growth of all 3 protozoa, but the growth rates on these organisms were less than the rates supported by the 2 bacteria, or by a mixture of the cyanobacteria and the bacterium Pseudomonas halodurans. The averaged growth rates for the 2 cultures with Synechococcus as the only prey were $20 \%$ (scuticociliate), $48 \%$ (hymenostome ciliate) and $74 \%$ (nanoflagellate) of the averaged growth rates of the 5 cultures with heterotrophic bacteria present. In the cultures containing only Synechococcus, cyanobacteria were readily ingested, as evidenced by microscopical examination that revealed that the protozoa in these cultures had very high densities of autofluorescent cells in their food vacuoles.

Although cyanobacteria were consumed in all treatments, protozoan cell yields (protozoa produced per unit of prey biomass consumed) in treatments where 
Table 2. Growth rates and maximum densities ( \pm 1 SD) of 3 species of protozoa fed 2 species of bacteria, 3 strains of chroococcoid cyanobacteria, or a combination of bacteria and cyanobacteria. Cultures marked by asterisks (") did not reach the stationary growth phase during the experimental period

\begin{tabular}{|c|c|c|c|c|c|c|}
\hline \multirow[t]{2}{*}{ Prey species } & \multicolumn{2}{|c|}{ Scuticociliate } & \multicolumn{2}{|c|}{ Hymenostome ciliate } & \multicolumn{2}{|c|}{ Paraphysomonas sp. } \\
\hline & $\begin{array}{c}\text { Growth rate } \\
\qquad\left(\mathrm{d}^{-1}\right)\end{array}$ & $\begin{array}{c}\text { Maximum } \\
\text { density } \\
\left(\text { no. } \mathrm{ml}^{-1} \text { ) }\right.\end{array}$ & $\begin{array}{l}\text { Growth rate } \\
\qquad\left(\mathrm{d}^{-1}\right)\end{array}$ & $\begin{array}{c}\text { Maximum } \\
\text { density } \\
\left(\text { no. } \mathrm{ml}^{-1}\right)\end{array}$ & $\begin{array}{c}\text { Growth rate } \\
\qquad\left(\mathrm{d}^{-1}\right)\end{array}$ & $\begin{array}{c}\text { Maximum } \\
\text { density } \\
\left(\text { no. } \mathrm{ml}^{-1} \text { ) }\right.\end{array}$ \\
\hline $\begin{array}{l}\text { Pseudomonas } \\
\text { halodurans }\end{array}$ & 6.7 & $8.47 \times 10^{4} \pm 1.44$ & 2.6 & $1.54 \times 10^{5} \pm 0.51$ & 5.5 & $2.38 \times 10^{6} \pm 0.56$ \\
\hline $\begin{array}{l}\text { Serratia } \\
\text { marinorubra }\end{array}$ & 6.2 & $5.15 \times 10^{4} \pm 1.15$ & 3.1 & $1.81 \times 10^{5} \pm 0.34$ & 5.3 & $1.53 \times 10^{6} \pm 0.23$ \\
\hline $\begin{array}{l}\text { Synechococcus } \\
\text { strain WH8101 }\end{array}$ & 0.5 & $-\cdot$ & 1.4 & $2.82 \times 10^{4} \pm 0.69$ & 3.4 & $7.95 \times 10^{4} \pm 0.15$ \\
\hline $\begin{array}{l}\text { Synechococcus } \\
\text { strain WH8012 }\end{array}$ & 1.9 & $9.78 \times 10^{3} \pm 3.18$ & 1.9 & $8.01 \times 10^{4} \pm 2.68$ & 4.1 & $8.55 \times 10^{5} \pm 0.76$ \\
\hline $\begin{array}{l}\text { Synechococcus } \\
\text { strain WH7803 }\end{array}$ & 1.4 & $4.87 \times 10^{3} \pm 0.96$ & 1.0 & $-{ }^{\cdot}$ & 4.3 & $3.58 \times 10^{5} \pm 0.73$ \\
\hline $\begin{array}{l}\text { P. halodurans } \\
\text { and WH8101 }\end{array}$ & 6.5 & $4.37 \times 10^{4} \pm 0.23$ & 3.6 & $8.23 \times 10^{4} \pm 0.61$ & 4.8 & $1.33 \times 10^{6} \pm 0.12$ \\
\hline $\begin{array}{l}\text { P. halodurans } \\
\text { and WH8012 }\end{array}$ & 6.5 & $8.03 \times 10^{4} \pm 2.77$ & 3.6 & $1.21 \times 10^{5} \pm 0.21$ & 5.3 & $1.79 \times 10^{6} \pm 0.09$ \\
\hline $\begin{array}{l}\text { P. halodurans } \\
\text { and WH } 7803\end{array}$ & 7.0 & $4.11 \times 10^{4} \pm 1.27$ & 2.4 & $8.37 \times 10^{4} \cdot 2.10$ & 5.5 & $1.15 \times 10^{6} \pm 0.19$ \\
\hline
\end{tabular}

Fig. 1. Examples of changes in cell densities of a scuticociliate and its prey in laboratory cultures when the ciliate was fed (A) Pseudomonas halodurans, (B) Synechococcus strain WH8012, (C) Synechococcus strain WH7803, and (D) a mixture of $P$. halodurans and Synechococcus strain WH7803
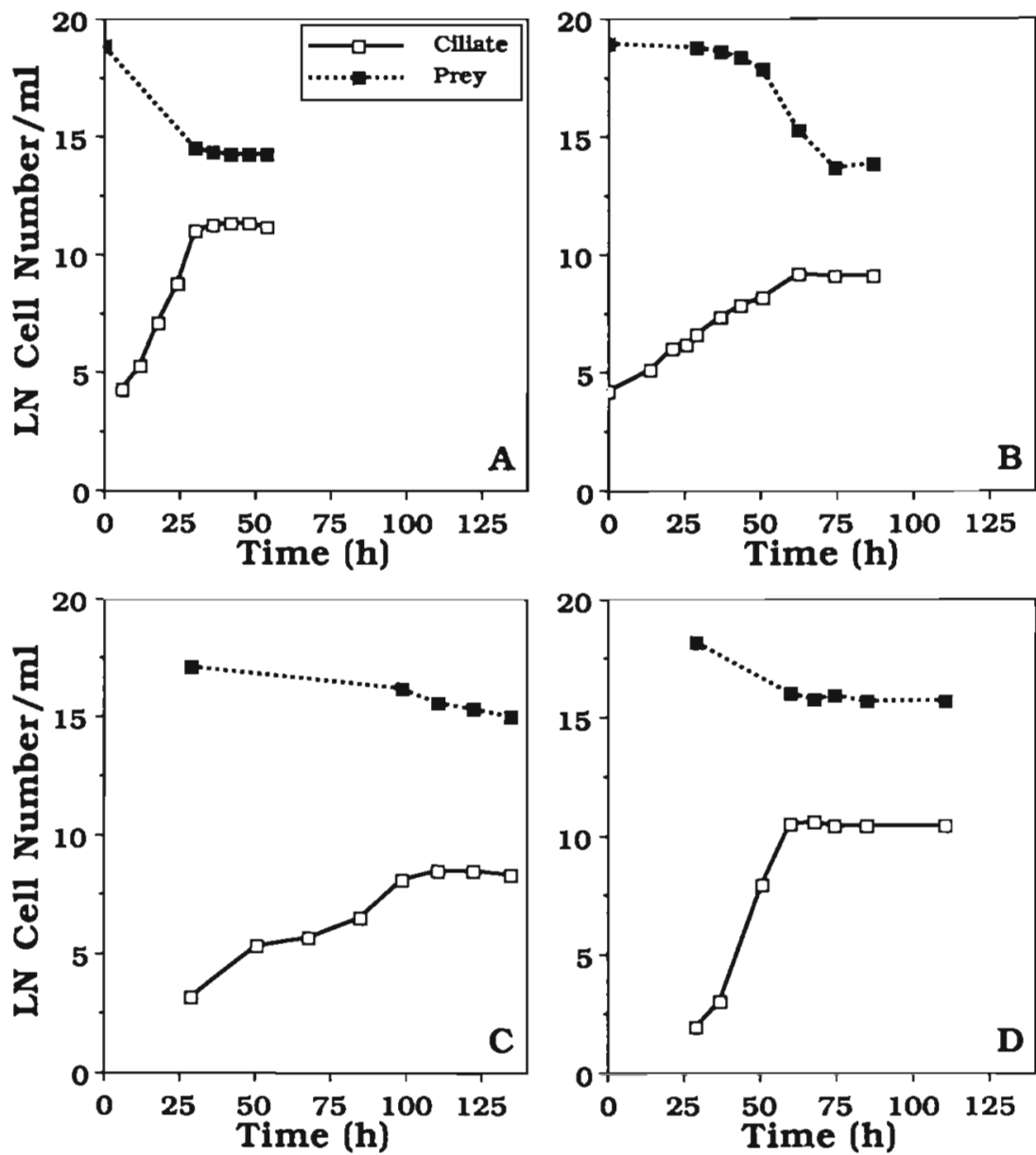
Synechococcus was the only prey were substantially lower than cell yields when heterotrophic bacteria were present (Table 2, Fig. 2). Synechococcus strain WH8012 produced the highest cell yield of the 3 cyanobacterial strains tested for all 3 protozoa, but the yields for this prey type were still only ca 20 to $60 \%$ of

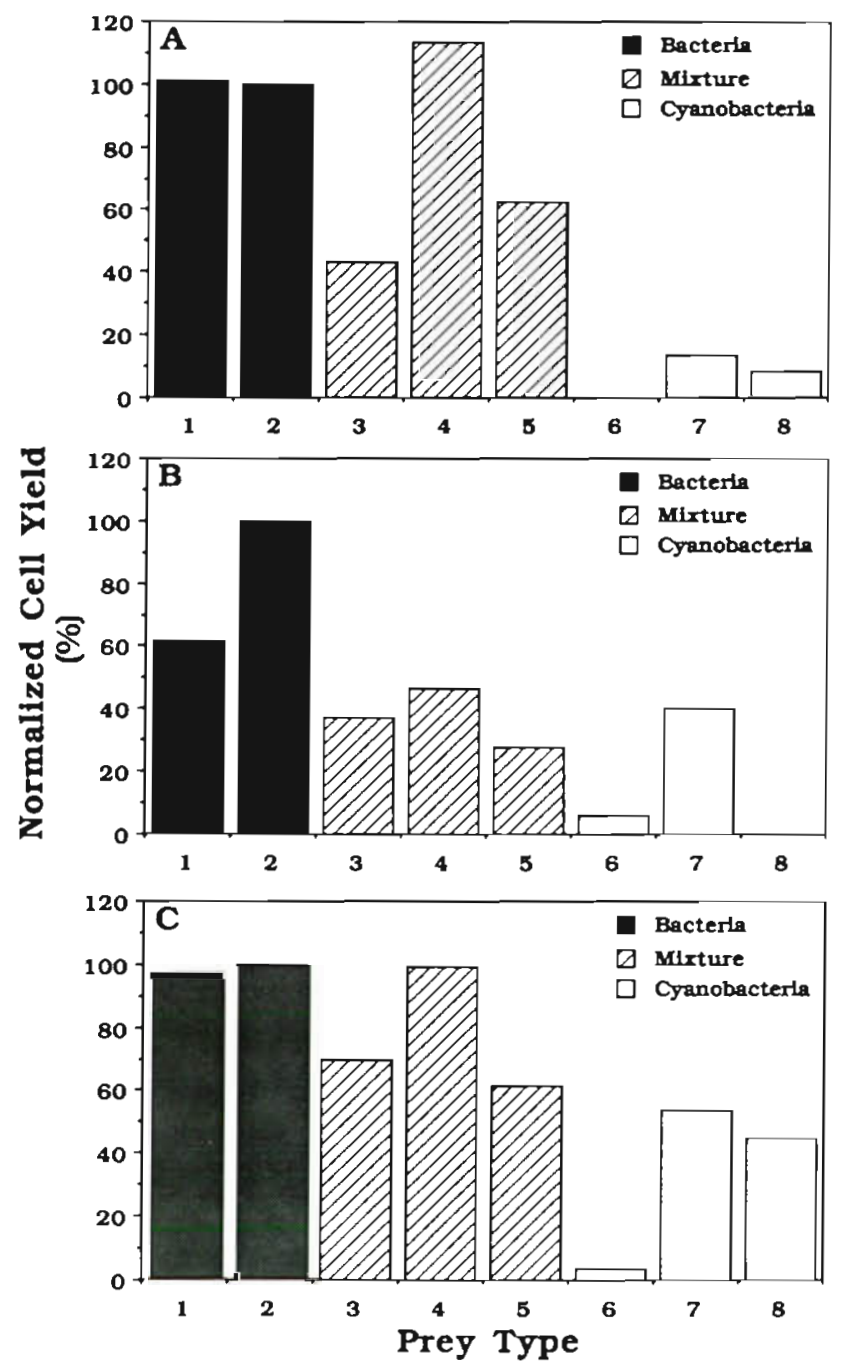

Fig. 2. Cell yields of (A) a scuticociliate, (B) a hymenostome ciliate and (C) the nanoflagellate Paraphysomonas sp., grown on the bacteria Pseudomonas halodurans (1) or Serratia marinorubra (2), the chroococcoid cyanobacteria Synechococcus strains WH8101 (6), WH8012 (7) or WH7803 (8), and a mixture of $P$. halodurans with strain WH8101 (3). WH8012 (4) or WH7803 (5). All yields have been normalized to the protozoan cell yield when grown on the bacterium Serratia marinorubra in order to facilitate comparisons between treatments. The actual gross growth efficiencies of the protozoa grown on $S$. marinorubra (based on the number of bacteria consumed, microscopical measurements of the protozoa and a carbon:volume conversion factor of $100 \mathrm{fg} \mathrm{C \mu m}{ }^{-3}$; Børsheim \& Bratbak 1987) were 30,67 and $41 \%$ for the scuticociliate, hymenostome ciliate and the nanoflagellate, respectively. Sizes of the protozoa did not vary significantly among treatments the yields obtained with heterotrophic bacteria (Fig. 2). In general, cell yields of protozoa cultured with mixtures of cyanobacteria and the bacterium Pseudomonas halodurans were intermediate to values obtained when the bacterium and the cyanobacteria were offered separately.

Protozoa grown in mixtures of heterotrophic bacteria and Synechococcus grew as rapidly as when heterotrophic bacteria alone were offered (Table 2). Microscopical examination of these treatments, however, revealed that in some cases the protozoa consumed primarily bacteria until the densities of these latter prey were substantially less than the densities of the cyanobacteria in the cultures. This selectivity was particularly acute for the scuticociliate. Very few ingested cyanobacteria were observed by epifluorescence microscopy in the scuticociliate during most of the exponential growth phase of this protozoan. Although we did not routinely distinguish cyanobacteria and bacteria during the cell counts, we did periodically count cyanobacteria fusing their autofluorescence to distinguish them) to confirm the feeding selectivity described above. For example at the time of inoculation of the scuticociliate into the treatment with Pseudomonas halodurans and Synechococcus strain WH7803, bacteria in the culture averaged $3.5 \times$ the density of the cyanobacteria. Near the end of exponential growth of the ciliate, this relationship had reversed and cyanobacterial density was $7.4 \times$ the density of the heterotrophic bacteria. Significant numbers of ingested Synechococcus were observed only after the bacterial density had been reduced in these cultures. In contrast, cyanobacteria were abundant in the food vacuoles of the hymenostome ciliate and the nanoflagellate when they were grown in mixtures of the 2 types of prey, and the ratio of bacteria to cyanobacteria in these latter cultures decreased only slightly during the exponential growth phases of the protozoa.

\section{Field studies}

Inhibitor effects

The eukaryote inhibitors colchicine and cyclohexamide had no discernable effect on the growth of Synechococcus strain WH7803 (Fig. 3). Growth rates calculated for cultures with and without the metabolic inhibitors were virtually identical. This result is consistent with a previous investigation of the effects of eukaryote inhibitors on chroococcoid cyanobacteria (Campbell \& Carpenter 1986).

The eukaryotic metabolic inhibitors greatly reduced the eukaryote grazing rate and the total number of eukaryotes ingesting prey, but this treatment did not 


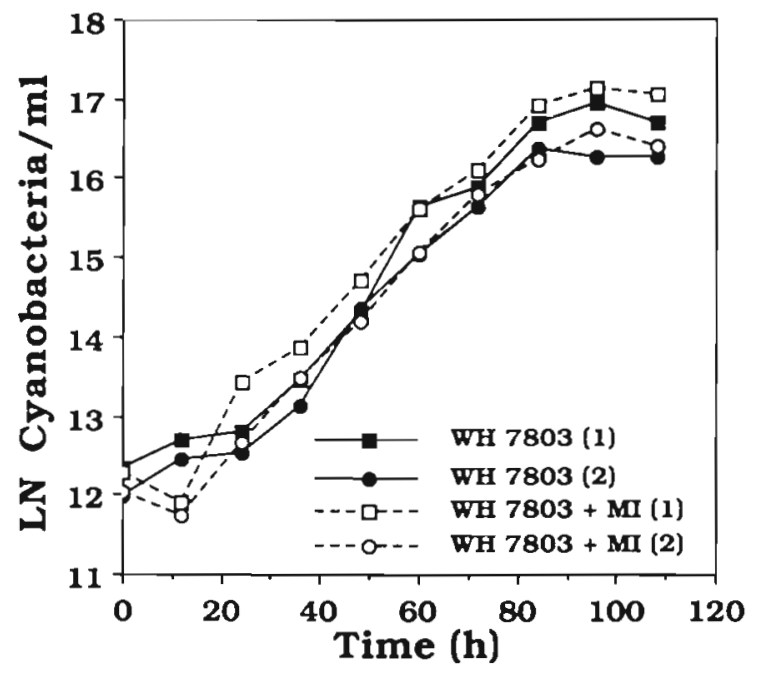

Fig. 3. Synechococcus strain WH7803. Growth in SN medium with eukaryotic metabolic inhibitors present (designated 'MI'; dashed lines) and without inhibitors (solid lines). (1) and (2) are replicate treatments

eliminate all grazing activity. The grazing rates obtained in this study must therefore be viewed as conservative estimates. The ingestion of fluorescent microspheres in a natural seawater sample during the first hour of incubation was undetectable in the inhibited samples, but ingested microspheres were observed in protozoa in the inhibited samples after $3 \mathrm{~h}$. Based on a comparison of the uptake rate of microspheres in samples with and without inhibitors, we estimated that ca $15 \%$ of the grazing activity continued in the presence of the eukaryotic inhibitiors. The percentage of protozoa with ingested microspheres was never more than $1 / 3$ of the maximum number observed in the uninhibited samples (i.e. some organisms apparently were completely inhibited over the $24 \mathrm{~h}$ period).

\section{Grazing rate measurements}

Our experiments were conducted during the seasonal bloom of Synechococcussp. in coastal waters near Woods Hole, and the population densities of Synechococcus at our study site increased by ca 1 order of magnitude over the course of the study (Table 3 ). In contrast, the densities of bacteria and heterotrophic nanoplankton were remarkably similar on the sampling dates.

Changes in population densities for cyanobacteria and bacteria during the experiment performed on 9 June are given in Fig. 4, and are representative of the changes observed in the other experiments. Increases in the density of the heterotrophic nanoplankton during these experiments were variable but in most cases were not greater than $10 \%$.
Table 3. Densities $( \pm 1 \mathrm{SD})$ of chroococcoid cyanobacteria (PPIC $=$ phototrophs $<2 \mu \mathrm{m})$, heterotrophic bacteria $(\mathrm{HPIC}=$ heterotrophs $<2 \mu \mathrm{m}$ ) and heterotrophic nanoplankton (HNAN $=$ heterotrophs 2 to $20 \mu \mathrm{m}$ ) in Vineyard Sound, Woods Hole, MA, on sampling dates in June and July 1987

\begin{tabular}{|llll|}
\hline Date & \multicolumn{3}{c|}{ Cell density (no. ml } \\
& PPIC & HPIC & HNAN \\
\hline \multirow{2}{*}{ 2 June } & - & $2.35 \times 10^{6}$ & - \\
& & \pm 0.20 & \\
9 June & $6.64 \times 10^{3}$ & $2.42 \times 10^{6}$ & $1.55 \times 10^{3}$ \\
& \pm 0.35 & \pm 0.09 & \pm 0.48 \\
16 June & $5.97 \times 10^{3}$ & $2.43 \times 10^{6}$ & $1.30 \times 10^{3}$ \\
& \pm 0.40 & \pm 0.10 & \pm 0.32 \\
29 June & $1.88 \times 10^{4}$ & $2.48 \times 10^{6}$ & $1.91 \times 10^{3}$ \\
& \pm 0.15 & \pm 0.24 & \pm 0.37 \\
28 July & $4.44 \times 10^{4}$ & $2.24 \times 10^{6}$ & $1.76 \times 10^{3}$ \\
& \pm 0.55 & \pm 0.17 & \pm 0.47 \\
& & & \\
\hline
\end{tabular}

Growth rates of the bacterial assemblage calculated from the increases of the cell densities over $24 \mathrm{~h}$ in the metabolically inhibited samples were significant in most cases (range $=0.00$ to $0.47 \mathrm{~d}^{-1}$ ) but there was consistently no significant increase in the number of Synechococcus in the inhibited samples. This result was unexpected because the in situ population was increasing during at least 3 of the experimental periods $(2,9$, and 16 June). Nitrogen and phosphorus enrichment of unfiltered seawater containing metabolic inhibitors did not promote the growth of Synechococcus in any of the experiments. Seawater samples incubated at a variety of light intensities to investigate the possibility of light inhibition or phototoxicity (see 'Materials and methods') also showed no significant growth of Synechococcus sp. In addition, 2 experiments in which seawater without inhibitors, seawater with inhibitors, and $\mathrm{a}<1.0 \mu \mathrm{m}$ filtrate were incubated in the laboratory $\left(22^{\circ} \mathrm{C}\right.$ in continuous light at $\left.60 \mu \mathrm{E} \mathrm{m}^{-2} \mathrm{~s}^{-1}\right)$ also yielded no significant growth of Synechococcus sp. in the inhibited treatments or in the $<1.0 \mu \mathrm{m}$ filtrate of these experiments, although large decreases in Synechococcus density were often observed in the unfiltered seawater samples of these experiments (i.e., in the presence of grazer activity).

Although growth of Synechococcus was not observed in our experiments, significant differences in cyanobacterial density were apparent between metabolically inhibited treatments and the corresponding unfiltered seawater, $<210 \mu \mathrm{m}$ and $<20 \mu \mathrm{m}$ fractions in all experiments (Table 4). Based on these differences, a range of 22 to $54 \%$ of the cyanobacterial population was removed daily during these experiments. Similar results were obtained for removal of the bacterial assemblage, although the range was greater (ca 1 to $75 \%$ ). The average decreases in the cyano- 

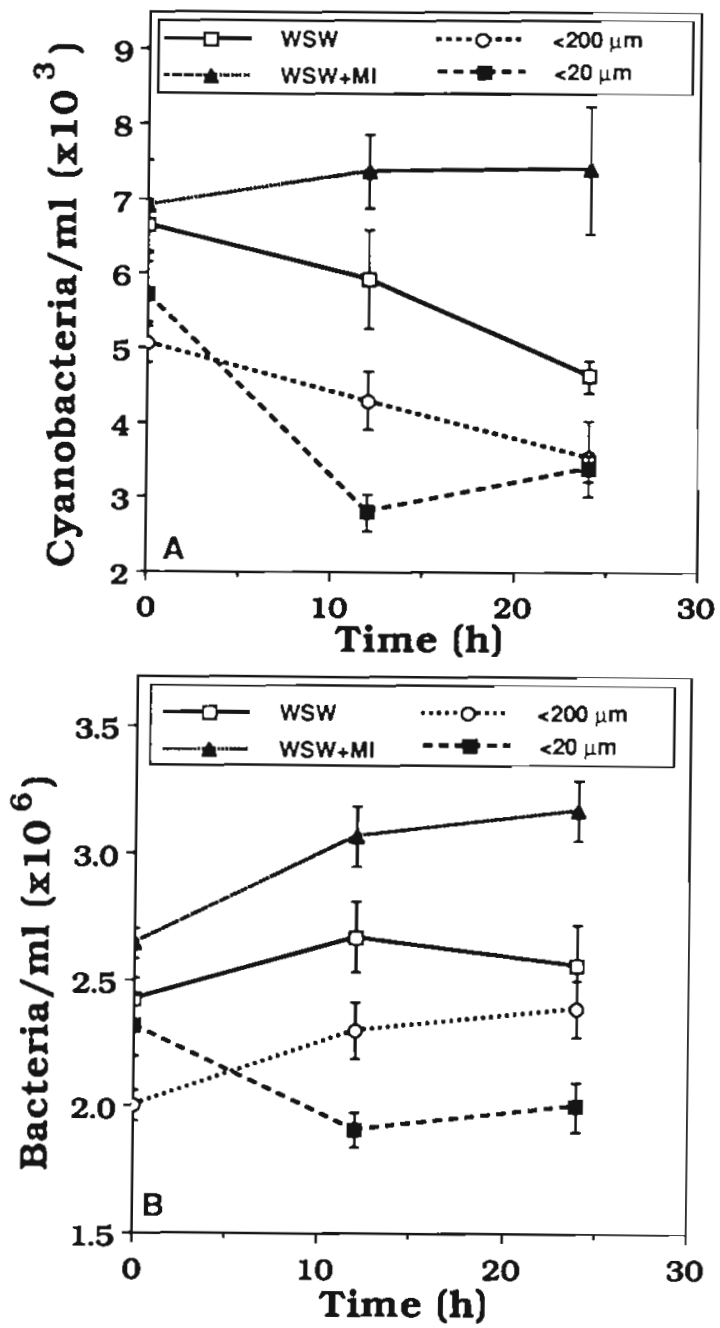

Fig. 4. Changes in the density of (A) the Synechococcus assemblage and $(B)$ the heterotrophic bacterial assemblage, in various treatments of a grazing experiment performed on a seawater sample collected from Vineyard Sound, MA, on 9 June 1987 Treatments were: unfiltered whole seawater (WSW), seawater + metabolic inhibitors (WSW + Ml), seawater filtered through $210 \mu \mathrm{m}$ screening $(<200 \mu \mathrm{m})$, and seawater filtered through $20 \mu \mathrm{m}$ screening $(<20 \mu \mathrm{m})$. Error bars respresent \pm 1 standard deviation of the mean of duplicate treatments

bacterial and bacterial populations in the 5 experiments were 36 and $32 \%$, respectively, in the unfiltered seawater samples.

Nanoplankton were unquestionably the major consumers of both bacteria and cyanobacteria in all experiments. Decreases in the population abundances of bacteria and cyanobacteria in the $<210 \mu \mathrm{m}$ and $<20 \mu \mathrm{m}$ treatments in general were comparable to, and were often greater than, decreases in the corresponding unfiltered samples (Table 4; Fig. 4). That is, removal of the microzooplankton and zooplankton did not result in a reduction in the rates of removal of Synechococcus or bacteria in most cases.
Ingestion rates and clearance rates of the natural assemblage of heterotrophic nanoplankton (HNAN) for cyanobacteria and bacteria were estimated from the average HNAN densities over the course of the experiments, the densities of the 2 prokaryotic populations, and the change in the densities of these prey populations (Table 5). Our observations have revealed that phagotrophic phytoflagellates constitute a minor portion (usually $<5 \%$ of the nanoplankton) of the bacterivorous nanoplankton in Vineyard Sound during summer, so we expect that heterotrophic nanoplankton are the major consumers of picoplankton in the $<20 \mu \mathrm{m}$ size class. Overall, ingestion rates for bacterial prey were ca 2 orders of magnitude greater than ingestion rates for cyanobacterial prey. The rate of ingestion of nanoplankton for Synechococcus was greater in July than earlier in the year, undoubtedly a consequence of the much higher cyanobacterial density in the water in July (Table 3). Unlike the estimated ingestion rates, clearance rates of the heterotrophic nanoplankton were similar for bacterial and cyanobacterial prey (overall range $=4.6$ to $17 \mathrm{nl} \mathrm{HNAN}^{-1} \mathrm{~h}^{-1}$ ).

Ingestion of organic carbon was estimated for the HNAN assemblage using the ingestion rates of Table 5 and conversion factors of 60 to $350 \mathrm{fg} \mathrm{C}^{\mathrm{C}} \mathrm{cell}^{-1}$ for Synechococcus (from Table 1) and $9.54 \mathrm{fg} \mathrm{C} \mathrm{Cell}^{-1}$ for bacteria (assuming an average bacterial cell volume of $0.09 \mu^{3}$ cell $^{-1}$ according to Ferguson \& Rublee 1976 ,

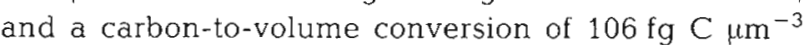
according to Nagata 1986). Because of the greater carbon content cell ${ }^{-1}$ for cyanobacteria, the ingestion of cyanobacteria represented a greater fraction of the total prokaryote biomass ingested by the heterotrophic nanoplankton assemblage than the ingestion rates of Table 5 would seem to indicate. For the range of conversion factors given above, we estimate that cyanobacterial biomass constituted 4 to $20 \%$ of the total picoplankton biomass consumed by the HNAN assemblage on 9 June, 2 to $12 \%$ on 16 June and 11 to $41 \%$ on 28 July. The Synechococcus population in Vineyard Sound typically is dominated by cells that are comparable in size to the cultured strain WH8012. The contribution of Synechococcus to the diets of the HNAN assemblage in this environment, therefore, probably was closer to the lower values for these ranges. Nevertheless, based on these calculations Synechococcus constituted at least $10 \%$ of the prokaryotic biomass ingested during the July experiment.

\section{DISCUSSION}

Chroococcoid cyanobacteria and heterotrophic bacteria contribute significantly to the living biomass of planktonic communities, and to the diets of organisms 
Table 4. Daily population changes for chroococcoid cyanobacteria and heterotrophic bacteria in unfiltered seawater and 2 size fractions. Changes represent differences between seawater samples without eukaryotic metabolic inhibitors and samples treated with inhibitors. The $<20 \mu \mathrm{m}$ size fraction was prepared by first filtering seawater through $210 \mu \mathrm{m}$ netting and then passing this filtrate through $20 \mu \mathrm{m}$ netting

\begin{tabular}{|c|c|c|c|c|}
\hline $\begin{array}{l}\text { Picoplankton } \\
\text { component }\end{array}$ & $\begin{array}{l}\text { Dates } \\
(1987)\end{array}$ & Seawater & $\begin{array}{l}\text { population ch } \\
<210 \mu \mathrm{m} \\
\text { size fraction }\end{array}$ & $\begin{array}{c}<20 \mu \mathrm{m} \\
\text { size fraction }\end{array}$ \\
\hline Cyanobacteria & $\begin{array}{l}2 \text { June } \\
9 \text { June } \\
16 \text { June } \\
29 \text { June } \\
28 \text { July } \\
\text { Mean }\end{array}$ & $\begin{array}{l}- \\
38 \\
54 \\
29 \\
22 \\
36\end{array}$ & $\begin{array}{l}- \\
38 \\
47 \\
45 \\
30 \\
40\end{array}$ & $\begin{array}{l}- \\
48 \\
46 \\
43 \\
33 \\
43\end{array}$ \\
\hline Heterotrophic bacteria & $\begin{array}{l}2 \text { June } \\
9 \text { June } \\
16 \text { June } \\
29 \text { June } \\
28 \text { July } \\
\text { Mean }\end{array}$ & $\begin{array}{c}52 \\
14 \\
33 \\
- \\
30 \\
32\end{array}$ & $\begin{array}{r}75 \\
1 \\
24 \\
38 \\
61 \\
40\end{array}$ & $\begin{array}{l}56 \\
34 \\
10 \\
47 \\
49 \\
39\end{array}$ \\
\hline
\end{tabular}

Table 5. Estimated ingestion rates and clearance rates of heterotrophic nanoplankton (HNAN) for bacteria and chroococcoid cyanobacteria in seawater samples during experiments conducted in June and July 1987. Rates are expressed as cells HNAN $^{-1} \mathrm{~d}^{-1}$ (ingestion rates) and $\mathrm{nl}$ HNAN $^{-1} \mathrm{~h}^{-1}$ (clearance rates). Values in parentheses are pg of carbon ingested, estimated from literature values for bacterial and cyanobacterial biomass (see text)

\begin{tabular}{|c|c|c|c|}
\hline $\begin{array}{l}\text { Picoplankton } \\
\text { component }\end{array}$ & Date & $\begin{array}{l}\text { Ingestion } \\
\text { rate }\end{array}$ & $\begin{array}{c}\text { Clearance } \\
\text { rate }\end{array}$ \\
\hline Cyanobacteria & $\begin{array}{l}9 \text { June } \\
16 \text { June } \\
29 \text { June } \\
28 \text { July }\end{array}$ & $\begin{array}{l}1.7(0.1-0.6) \\
2.4(0.1-0.8) \\
2.9(0.2-1.0) \\
5.5(0.3-1.9)\end{array}$ & $\begin{array}{c}11 \\
17 \\
6.3 \\
5.0\end{array}$ \\
\hline $\begin{array}{l}\text { Heterotrophic } \\
\text { bacteria }\end{array}$ & $\begin{array}{l}9 \text { June } \\
16 \text { June } \\
29 \text { June } \\
28 \text { July }\end{array}$ & $\begin{array}{c}252(2.4) \\
624(5.9) \\
- \\
290(2.7)\end{array}$ & $\begin{array}{c}4.6 \\
11 \\
-- \\
5.4\end{array}$ \\
\hline
\end{tabular}

capable of capturing and digesting these minute prey. Because of the important role that these prokaryotic microorganisms play in the production and transformation of organic material in the ocean, identifying the consumers of this biomass and quantifying their rates of consumption by higher organisms have become foci of study in aquatic microbial ecology.

Previous studies with cultured or natural populations of protozoa grazing on chroococcoid cyanobacteria have been concerned primarily with the ability of these organisms to ingest cyanobacteria. Utilization of the ingested biomass has not been adequately addressed. Johnson et al. (1982) demonstrated the maintenance of the helioflagellate Actinomonas sp. for more than $1 \mathrm{yr}$ with periodic additions of cultured cyanobacteria (bacteria were also present). These authors also demonstrated rapid growth of the ciliate Uronema sp. on a mixed diet of chroococcoid cyanobacteria and heterotrophic bacteria. In addition, several studies have noted ingested Synechococcus in a variety of planktonic protozoa and micrometazoa (Caron et al. 1985b, 1986, Iturriaga \& Mitchell 1986). While these studies have established that protozoa can use cyanobacteria to supplement their nutrition, they have not clearly established whether or not the biomass constituted a highquality food for these consumers.

Our laboratory studies with cultured species of protozoa indicated that cyanobacterial prey supported slower growth rates and lower cell yields of the protozoa (particularly the ciliates) than were supported by heterotrophic bacterial prey. Overall, the nanoflagellates appeared to be more capable of utilizing this biomass than the ciliates. Paraphysomonas sp. grew reasonably well on all 3 Synechococcus strains (Table 2). The growth rates of Paraphysomonas sp. fed Synechococcus averaged ca $75 \%$ of the average growth rate with heterotrophic bacteria alone or with mixtures of the 2 types of prey, while growth rates of the 2 ciliates were substantially lower (ca 20\% and $50 \%$ of the growth rates on bacteria). An inability to capture and ingest the cyanobacteria cannot completely explain the lower growth rates of these organisms on a cyanobacterial diet. All 3 species were observed to contain ingested cyanobacteria when they were the only food available. Instead, it would appear that the growth rates of the protozoa may have been affected by the digestibility of the cyanobacterial cells, or by a limiting quantity of some compound(s) in the 
cyanobacterial biomass that was required by the protozoa for growth.

Although it was clear in our laboratory study that the growth rates of the 3 protozoa feeding on cyanobacterial prey were slower than rates when they were feeding on bacteria, several questions remain concerning the extrapolation of these data to nature. We made no attempt to specificaliy isolate species of protozoa that might be adapted to utilizing chroococcoid cyanobacteria. The protozoa used here were isolated from seawater samples enriched with heterotrophic bacteria, not cyanobacteria, and it is possible that protozoa exist that are adapted to growing rapidly on cyanobacteria. In particular, the ciliates tested here are not very representative of ciliates from most plankton communities. Bacterial sizes were $3 \times$ the sizes of natural bacterial assemblages and prey abundances were several orders of magnitude greater than abundances in nature. Furthermore, we observed greater cell yields for protozoa grown with a mixture of bacterial and cyanobacterial prey compared to yields when only cyanobacteria were present (Fig. 2). The hymenostome ciliate and the nanoflagellate, in particular, were able to grow rapidly on a mixture of heterotrophic bacteria and chroococcoid cyanobacteria, and there was little evidence of selectivity against the cyanobacteria. In nature it would be expected that a combination of bacterial and cyanobacterial prey would be ingested by picoplankton consumers, so the ability to utilize cyanobacterial biomass in combination with other prey organisms may be particularly important.

Some of the poor growth of the cultured protozoa that we observed when they were fed only cyanobacteria presumably was a consequence of food quality. Based on the carbon content of the cyanobacteria, the number of cyanobacteria consumed and the number of protozoa produced, the growth efficiencies of the protozoa grown on these prey organisms were considerably less than the growth efficiencies on heterotrophic bacteria (Fig. 2). The size of the protozod did not vary significantly among the treatments, and cannot account for the large differences in protozoan yield. Synechococcus strain WH8101, a particularly poor food for the 3 protozoa tested, is not a common marine isolate (Waterbury et al. 1986) and may be unrepresentative of the type of Synechococcus strains commonly encountered by marine protozoa.

The poor growth efficiencies of the protozoa when offered cyanobacteria alone imply that a considerable amount of the organic material contained in the cyanobacteria may have been released as undigested dissolved and particulate organic matter. Interestingly. Hagström et al. (1988) determined that a substantial percentage $(60 \%)$ of the total primary pro- duction of a pelagic marine environment was converted to dissolved organic matter and thereby made available to heterotrophic bacteria. They postulated that a major source of this pool of dissolved organic matter occurred by the production and subsequent consumption of picoplanktonic cyanobacteria. Our observation of low growth yield on a cyanobacterial diet indirectly supports the contention of Hagström et al. (1988).

Ingestion rates of heterotrophic nanoplankton in our field experiments were 2 orders of magnitude greater for bacterial prey than for cyanobacterial prey, but these differences can be attributed to the great disparity in the densities of the 2 prey assemblages (Tables 3 $\& 5)$. Clearance rates of the heterotrophic nanoplankton were similar for both prey types (overall range = 4.6 to $17 \mathrm{nl}$ HNAN $^{-1} \mathrm{~h}^{-1}$; Table 5). These rates are within the range of published clearance rates for cultured species of bacterivorous nanoflagellates (Davis 1982, Fenchel 1982, Sherr et al. 1983, Davis \& Sieburth 1984, Caron et al. 1985a). Based on these clearance rates we conclude that Synechococcus and heterotrophic bacteria were removed from the water at similar filtration efficiencies, and that protozoa did not appear to select for or against Synechococcus in nature.

If this behavior is representative of HNAN communities, then chroococcoid cyanobacteria may contribute very significantly to the diets of small protozoa at times of peak cyanobacterial abundances. The highest cyanobacterial abundance in this study $\left(4.44 \times 10^{4}\right.$ $\mathrm{ml}^{-1}$ ) was lower than the annual peak abundance in Vineyard Sound by a factor of $3 \times$ (Waterbury et al. 1986). On occasions when Synechococcus abundance reaches $>10^{5} \mathrm{ml}^{-1}$ this biomass may constitute $>30 \%$ of the prokaryotic biomass (assuming a bacterial density similar to densities observed in this study). This estimate assumes a carbon content of Synechococcus of $60 \mathrm{fg} \mathrm{C} \mathrm{cell}^{-1}$ (Table 1). In situations where Synechococcus abundance is higher or Synechococcus size is larger, cyanobacterial biomass has been shown to be greater than $50 \%$ of the prokaryotic biomass (Caron et al. 1985b, Pick \& Caron 1987). Under these latter circumstances chroococcoid cyanobacteria were commonly observed in the food vacuoles of nanoplanktonic grazers, and their contribution to the nutrition of these small protozoa was presumed to be considerable (Pick \& Caron 1987).

Rates of removal of Synechococcus by natural grazer assemblages in this study ranged from 22 to $54 \%$ of the population removed $d^{-1}$ (Table 4). These values are comparable to removal rates observed in other field studies (Landry et al. 1984, Campbell \& Carpenter 1986). Assuming that the cyanobacterial population was not decreasing in abundance in nature, a minimum 
growth rate of ca 1 division every $2 \mathrm{~d}$ would be required to maintain the cyanobacterial density against the upper range of this predation pressure. Because there was a net increase in the cyanobacterial density during most of our study period (Table 3; also Waterbury et al. 1986), the growth rate of the Synechococcus assemblage must have been greater than this predation pressure during this time.

Removal of the plankton $>210 \mu \mathrm{m}$ and $>20 \mu \mathrm{m}$ did not decrease the rates of removal of cyanobacteria and bacteria (Table 4; Fig. 4). This result indicates an important role for nanoplanktonic grazers as consumers of these assemblages. This is not an unexpected result, and is in agreement with recent conceptualizations of the trophic relationships of planktonic microbial food webs (Azam et al. 1983). It is probable that some organisms larger than $20 \mu \mathrm{m}$ made it through the $20 \mu \mathrm{m}$ screen, but most recent studies have demonstrated that the consumers of bacteria-sized particles in the ocean are small $(<5 \mu \mathrm{m})$ nanoplankton (Wikner \& Hagstrom 1988). The increases in removal rates that often occurred when larger consumers were removed (Table 4; Fig. 4) may be a result of a reduction in the density of organisms that consume nanoplankton. Heterotrophic nanoplankton increased slightly in abundance in some but not all of the fractionated samples (range $=0$ to $1.2 \times$ ) over the $24 \mathrm{~h}$ incubation period.

Two important caveats in our field experiments require comment. First, although the eukaryote inhibitors greatly reduced grazing in the Vineyard Sound samples, they did not stop all grazing from taking place. We estimated that, at the very least, grazing was reduced by ca $85 \%$. Because some undetermined fraction of the grazing was not halted, however, our estimates of grazing must be considered conservative estimates. Second, Synechococcus in general did not grow in our experimental vessels. The lack of cyanobacterial growth in the eukaryote-inhibited treatments of the grazing experiments presumably was not attributable to a deleterious effect of the inhibitor on Synechococcus because our laboratory study with Synechococcus strain WH7803 revealed no effect. In addition, we observed no growth of cyanobacteria in the $<1.0 \mu \mathrm{m}$ filtrate even though metabolic inhibitors were not present. An interruption of the nutrient supply and/or light intensity also was not the reason for this lack of growth because nutrient supplementation and several light regimes had no measurable effect. In our calculation of grazing rates we assumed that Synechococcus acted the same in our incubation vessels as it did in nature. If growth of Synechococcus was depressed in our containers, then this effect also would have resulted in the calculation of a conservative grazing rate.
The results of our study clearly indicate an important role for chroococcoid cyanobacterial biomass as a food source for nanoplanktonic protozoa at times when cyanobacteria were abundant. Although relatively few cyanobacteria were consumed on a daily basis (compared to bacteria), their large size relative to planktonic bacteria resulted in a significant contribution to the total ingested prokaryote carbon. From our laboratory studies with 3 species of bacterivorous protozoa we conclude that Synechococcus probably is not a good food source for at least some bacterivorous protozoa when it is the only food consumed. However, it is highly unlikely that such a situation would arise in nature. In most (if not all) freshwater and marine environments, heterotrophic picoplankton density exceeds phototrophic picoplankton density by at least 1 or 2 orders of magnitude (Davis et al. 1985, Stockner \& Antia 1986, Waterbury et al. 1986, Pick \& Caron 1987). Therefore, cyanobacterial carbon in all probability will constitute only a portion of the total carbon ingested by protozoa in most planktonic ecosystems. Our laboratory results indicate that when it is consumed with other suitable prey, at least some species of protozoa appear to be capable of effectively utilizing cyanobacterial biomass. In these situations chroococcoid cyanobacteria may be an important ancillary food source for planktonic protozoa.

Acknowledgements. The authors gratefully acknowledge the assistance of Ms Kay Ho in conducting this study. This work was supported by National Science Foundation grants OCE8600510 (D.A.C.), OCE-8901005 (D.A.C.) and BSR-8607386 (J.B.W.), the Woods Hole Oceanographic Institution Summer Fellowship Program, the Five Colleges Coastal and Marine Sciences Program, a Smith C. Dana Internship Grant, and a grant from the Florence and John Schumann Foundation. Woods Hole Oceanographic Institution Contribution No. 7705 .

\section{LITERATURE CITED}

Azam, F., Fenchel, T., Field, J. G., Meyer-Reil, L. A., Thingstad, F. (1983). The ecological role of water-column microbes in the sea. Mar Ecol. Prog. Ser. 10: 257-263

Børsheim, K. Y., Bratbak, G. (1987). Cell volume to cell carbon conversion factors for a bacterivorous Monas sp. enriched from seawater. Mar. Ecol. Prog. Ser. 36: 171-175

Campbell, L., Carpenter, E. J. (1986). Estimating the grazing pressure of heterotrophic nanoplankton on Synechococcus spp. using the sea water dilution and selective inhibitor techniques. Mar. Ecol. Prog. Ser. 33: 121-129

Caron, D. A., Goldman, J. C., Andersen, O. K., Dennett, M. R. (1985a). Nutrient cycling in a microflagellate food chain. II. Population dynamics and carbon cycling. Mar. Ecol. Prog. Ser. 24: 243-254

Caron, D. A., Pick, F. R., Lean, D. R. S. (1985b). Chroococcoid cyanobacteria in Lake Ontario: vertical and seasonal distributions during 1982. J. Phycol. 21-171-175

Caron, D. A., Davis, P. G., Madin, L. P., Sieburth, J. McN. 
(1986). Enrichment of microbial populations in macroaggregates (marine snow) from surface waters of the North Atlantic. J. mar. Res. 44: 543-565

Chang, V T.-P. (1980). Zwei neue Synechococcus-Arten aus dem Zürichsee. Schweiz. Z. Hydrol. 42: 247-254

Cole, J. J., Findlay, S., Pace, M. L. (1988). Bacterial production in fresh and saltwater ecosystems: a cross-system overview. Mar. Ecol. Prog. Ser. 43: 1-10

Cronberg, G., Weibull, C. (1981). Cyanodictyon imperfectum, a new chroococcal blue-green alga from Lake Trummen, Sweden. Arch Hydrobiol. Suppl. 60: 101-110

Cuhel, R. L., Waterbury, J. B. (1984). Biochemical composition and short-term nutrient incorporation patterns in a unicellular marine cyanobacterium, Synechococcus sp. Limnol. Oceanogr. 29: 370-374

Davis, P. G. (1982). Bacterivorous flagellates in marine waters. Ph.D. dissertation, University of Rhode Island, Kingston

Davis, P. G., Caron, D. A., Johnson, P. W., Sieburth, J. McN. (1985). Phototrophic and apochlorotic components of picoplankton and nanoplankton in the North Altantic: geographic, vertical, seasonal and diel distributions. Mar. Ecol. Prog. Ser 21, 15-26

Davis, P. G., Sieburth, J. McN. (1982). Differentiation of the photosynthetic and heterotrophic populations of nanoplankters by epifluorescence microscopy. Annls Inst. océanogr., Paris 58 (S): 249-259

Davis, P. G., Sieburth, J. McN. (1984). Estuarine and oceanic microflagellate predation of actively growing bacteria. estimation by frequency of dividing-divided bacteria. Mar Ecol. Prog. Ser. 19: 237-246

Fahnenstiel, G. L., Sicko-Goad, L., Scavia, D. Stoermer, E. F. (1986). Importance of picoplankton in Lake Superior. Can. J. Fish. Aquat. Sci. 43: 235-240

Fenchel, T. (1982). Ecology of heterotrophic microflagellates. II. Bioenergetics and growth. Mar. Ecol. Prog. Ser 8: 225-231

Ferguson, R. L., Rublee, P. (1976). Contribution of bacteria to standing crop of coastal plankton. Limnol. Oceanogr. 21: 141-145

Fuhrman, J. A., Azam, F. (1982). Thymidine incorporation as a measure of heterotrophic bacterioplankton production in marine surface waters: evaluation and field results. Mar Biol. 66: 109-120

Glover, H. E. (1985). The physiology and ecology of the marine cyanobacterial genus Synechococcus. Adv. aquat. Microbiol. 3: 49-107

Glover, H. E., Campbell, L., Prezelin, B. B. (1986). Contribution of Synechococcus spp. to size-fractioned primary productivity in three water masses in the northwest Atlantic Ocean Mar Biol. 91: 193-203

Glover, H. E., Prézelin, B. B., Campbell, L., Wyman, M. (1988). Pico- and ultraplankton Sargasso Sea communities: variability and comparative distributions of Synechococcus spp. and algae. Mar. Ecol. Prog. Ser 49: 127-139

Hagström, A., Azam, F, Andersson, A., Rassoulzadegan, F. (1988). Microbial loop in an oligotrophic pelagic marine ecosystem: possible roles of cyanobacteria and nanoflagellates in the organic fluxes. Mar. Ecol. Prog. Ser 49: $171-178$

Iturriaga, R., Mitchell, B. G. (1986). Chroococcoid cyanobacteria: a significant component in the food web dynamics of the open ocean. Mar Ecol. Prog. Ser. 28: 291-297

Johnson, P. W., Xu, H., Sieburth, J. McN. (1982). The utilization of chroococcoid cyanobacteria by marine protozooplankters but not by calanoid copepods. Annls Inst. océanogr., Paris 58(S): 297-308
Joint, I. R., Pomroy, A. J. (1983). Production of picoplankton and small nanoplankton in the Celtic Sea. Mar. Biol. 77 : 19-27

Krempin, D. W., Sullivan, C. E. (1981). The seasonal abundance, vertical distribution, and relative microbial biomass of chroococcoid cyanobacteria at a station in southern California coastal waters. Can. J. Microbiol. 27: $1341-1344$

Landry, M. R., Haas, L. W., Fagerness, V. L. (1984). Dynamics of microbial plankton communities: experiments in Kaneohe Bay, Hawaii. Mar. Ecol. Prog. Ser. 16: 127-133

Li, W. K. W., Rao, D. V. S., Harrison, W. G., Smith, J. C., Cullen, J. J., Irwin, B, Platt T. (1983). Autotrophic picoplankton in the tropical ocean. Science 219: 292-295

McManus, G. B., Fuhrman, J. A. (1988). Control of marine bacterioplankton populations: measurement and significance of grazing. Hydrobiologia 159: 51-62

Morris, I., Glover, H. (1981). Physiology of photosynthesis by marine coccoid cyanobacteria - some ecological implications. Limnol. Oceanogr. 26: 957-961.

Murphy, L. S., Haugen, E. (1985). The distribution and abundance of phototropic picoplankton in the North Atlantic. Limnol. Oceanogr. 30: 47-58

Nagata, T. (1986). Carbon and nitrogen content of natural planktonic bacteria. Appl. environ. Microbiol. 52: 28-32

Olson, R. J., Chisholm, S. W., Zettler, E. R., Armbrust, E. V (1990). Pigments, size and distribution of Synechococcus in the North Atlantic and Pacific Oceans. Limnol. Oceanogr. 35: $45-58$

Pace, M. L. (1988). Bacterial mortality and the fate of bacterial production. Hydrobiologia 159:41-49

Pick, F. R., Caron, D. A. (1987). Picoplankton and nanoplankton biomass in Lake Ontario: relative contribution of phototrophic and heterotrophic communities. Can. J. Fish. Aquat. Sci, 44: 2164-2172

Platt, T., Rao, D. V. S., Irwin, B. (1983). Photosynthesis of picoplankton in the oligotrophic ocean. Nature, Lond. 301 : 702-704

Porter, K. G., Feig, Y. S. (1980). The use of DAPI for identifying and counting aquatic microflora. Limnol. Oceanogr. 25: 943-948

Sherr, B. F., Sherr, E. B., Berman, T. (1983). Grazing, growth, and ammonium excretion rates of a heterotrophic microflagellate fed four species of bacteria. Appl. environ. Microbiol. 45: 1196-1201

Sherr, B. F., Sherr, E. B., Andrew, T L., Fallon, R. D., Newell, S. Y (1986). Trophic interactions between heterotrophic protozoa and bacterioplankton in estuarine water analyzed with selective metabolic inhibitors. Mar Ecol. Prog Ser. 32: 169-179

Sieracki, M. E., Haas, L. W., Caron, D. A., Lessard, E. J. (1987). Effect of fixation on particle retention by microflagellates: underestimation of grazing rates. Mar. Ecol. Prog. Ser. 38: $251-258$

Stockner, J. G., Antia, N. J. (1986). Algal picoplankton from marine and freshwater ecosystems: a multidisciplinary perspective. Can. J. Fish. Aquat. Sci. 43: 2472-2503

Takahashi, M., Bienfang, P. K. (1983). Size structure of phytoplankton biomass and photosynthesis in subtropical Hawaiian waters. Mar Biol. 76: 203-211

Waterbury, J. B., Watson, S. W., Guillard, R. R. L., Brand, L. E. (1979). Widespread occurrence of a unicellular, marine, planktonic, cyanobacterium. Nature, Lond. 277 293-294

Waterbury, J. B., Watson, S. W. Valois, F. W (1980). Preliminary assessment of the importance of Synechococcus spp. 
as oceanic primary producers. In: Falkowski, P. (ed.) Primary production in the sea. Plenum Press, New York, p. $516-517$

Waterbury, J. B., Watson, S. W., Valois, F. W., Franks, D. G. (1986). Biological and ecological characterization of the marine unicellular cyanobacterium Synechococcus. Can. Bull. Fish. Aquat. Sci. 214: 71-120

This article was presented by M. R. Landry, Honolulu, Hawaii, USA
Weisse, T. (1989). The microbial loop in the Red Sea: dynamics of pelagic bacteria and heterotrophic nanoflagellates. Mar. Ecol. Prog. Ser. 55: 241-250

Wikner, J., Hagström, $\AA$. (1988). Evidence for a tightly coupled nanoplanktonic predator-prey link regulating the bacterivores in the marine environment. Mar Ecol. Prog. Ser. 50: $137-145$

Manuscript first received: January 11, 1991 Revised version accepted: July 29, 1991 